\title{
Immunohistochemical localization and mRNA expression of aquaporins in the macula utriculi of patients with Meniere's disease and acoustic neuroma
}

\author{
Gail Ishiyama • Ivan A. Lopez • Luis Beltran-Parrazal • \\ Akira Ishiyama
}

Received: 29 December 2009 / Accepted: 31 March 2010/Published online: 12 May 2010

(C) The Author(s) 2010. This article is published with open access at Springerlink.com

\begin{abstract}
Meniere's disease is nearly invariably associated with endolymphatic hydrops (the net accumulation of water in the inner ear endolymphatic space). Vestibular maculae utriculi were acquired from patients undergoing surgery for Meniere's disease and acoustic neuroma and from autopsy (subjects with normal hearing and balance). Quantitative immunostaining was conducted with antibodies against aquaporins (AQPs) 1,4 , and $6, \mathrm{Na}^{+} \mathrm{K}^{+}$ATPase, $\mathrm{Na}^{+} \mathrm{K}^{+} 2 \mathrm{Cl}$ co-transporter (NKCC1), and $\alpha$-syntrophin. mRNA was extracted from the surgically acquired utricles from subjects with Meniere's disease and acoustic neuroma to conduct quantitative real-time reverse transcription with polymerase chain reaction for AQP1, AQP4, and AQP6. AQP1 immunoreactivity (-IR) was located in blood vessels and fibrocytes in the underlying stroma, without any apparent alteration in Meniere's specimens when compared with
\end{abstract}

This research was supported by NIDCD-NIH grants DC005028, 5U24 DC008635, and DC005187.

G. Ishiyama

Neurology Department,

Division of Head and Neck "David Geffen" School of Medicine,

UCLA,

Los Angeles, CA, USA

I. A. Lopez $\cdot$ L. Beltran-Parrazal · A. Ishiyama

Surgery Department,

Division of Head and Neck "David Geffen" School of Medicine,

UCLA,

Los Angeles, CA, USA

A. Ishiyama $(\square)$

CHS 62-132, UCLA School of Medicine,

10833 Le Conte Avenue,

Los Angeles, CA 90095, USA

e-mail: ishiyama@ucla.edu acoustic neuroma and autopsy specimens. AQP4-IR localized to the epithelial basolateral supporting cells in Meniere's disease, acoustic neuroma, and autopsy. In specimens from subjects with Meniere's disease, AQP4-IR was significantly decreased compared with autopsy and acoustic neuroma specimens. AQP6-IR occurred in the subapical vestibular supporting cells in acoustic neuroma and autopsy samples. However, in Meniere's disease specimens, AQP6-IR was significantly increased and diffusely redistributed throughout the supporting cell cytoplasm. $\mathrm{Na}^{+} \mathrm{K}^{+}$ATPase, $\mathrm{NKCC} 1$, and $\alpha$-syntrophin were expressed within sensory epithelia and were unaltered in Meniere's disease specimens. Expression of AQP1, AQP4, or AQP6 mRNA did not differ in vestibular endorgans from patients with Meniere's disease. Changes in AQP4 (decreased) and AQP6 (increased) expression in Meniere's disease specimens suggest that the supporting cell might be a cellular target.

Keywords Inner ear Endolymphatic hydrops · Acoustic neuroma $\cdot \mathrm{Na}^{+} \mathrm{K}^{+}$ATPase $\cdot \mathrm{NKCC} 1 \cdot \alpha$-syntrophin .

Aquaporins $\cdot$ Human

\section{Introduction}

In 1861, Prosper Ménière described the classical triad of episodic vertigo, fluctuating sensorineural hearing loss, tinnitus and a feeling of aural pressure, and attributed this syndrome to an inner ear labyrinthine dysfunction (Baloh 2001). Many theories have been proposed regarding the pathophysiology of Meniere's disease, including anatomic abnormalities affecting endolymph resorption, vascular abnormalities, post-viral autoimmune mechanisms, and factors relating to water homeostasis (Merchant et al. 
2005; Minor et al. 2004; Paparella 1984). The first postmortem temporal bone studies in subjects with a history of Meniere's disease discovered a ballooning distension of the inner ear fluid-filled endolymphatic space (Hallpike and Cairns 1938; Yamakawa 1938). However, hydrops has been reported in asymptomatic subjects (Merchant et al. 2005; Rauch et al. 1989), indicating that endolymphatic hydrops is likely a necessary but not sufficient condition for the development of Meniere's disease. Because of the close association of endolymphatic hydrops with Meniere's disease, an alteration in the expression of water and ion channels has been proposed to disrupt inner ear fluid homeostasis in Meniere's disease (Andrews 2004; Semaan et al. 2005; Ishiyama et al. 2006). Numerous ion channels and water transporters involved in inner ear fluid homeostasis and maintaining the endolymphatic potential needed for hearing and balance function have been identified in the mammalian audiovestibular periphery (Beitz et al. 2003; Hibino and Kurachi 2006; Lang et al. 2007; Salt et al. 1987).

Aquaporins (AQPs) play a fundamental role in mediating bidirectional water transport across membranes by lowering the energy used for water permeation (Magni et al. 2006; Verkman and Mitra 2002). Presently, 13 members of the AQP family (AQP0-AQP12) are known (Agre et al. 2002). At least eight AQPs have been described in the inner ear (Beitz et al. 1999; Huang et al. 2002; Li and Verkman 2001; Lopez et al. 2007; Merves et al. 2005; Mhatre et al. 2002; Sawada et al. 2002; Stankovic et al. 1995; Takumi et al. 1998). The immunolocalization of AQP1, 4, and 6 has recently been described in the human inner ear obtained from subjects with normal hearing and balance, and the localization demonstrates conservation across animal models (Lopez et al 2007).

AQP1, an osmotic water channel in the kidney, brain, vascular system, and other tissues, has been hypothesized to function as a cGMP-gated cation channel (Boassa and Yool 2002; Boassa et al. 2006). The role of AQP1 that localizes to mesenchymal cells in the animal and human cochlea and vestibule has been proposed to be the transport of water molecules external to the endolymphatic compartment, regulating the osmotic environment adjacent to the scala media (Merves et al. 2005; Stankovic et al. 1995; Takumi et al. 1998).

AQP4 is critical for the movement of water from the blood or cerebrospinal fluid into and out of the brain tissue and is localized in the endfeet membranes directly in contact with the basement membranes (Amiry-Moghaddam and Ottersen 2003; Amiry-Moghaddam et al. 2004). In the inner ear, AQP4 is restricted to epithelial cells in the organ of Corti and vestibular supporting cells and has been hypothesized to offset local increases in $\mathrm{K}^{+}$ion concentration in supporting cells (Beitz et al. 2003; Takumi et al 1998; Lopez et al. 2007). AQP4 probably plays a critical role in hearing, as the AQP4 knockout mouse models exhibit impaired auditory function, although the inner ear morphology is normal (Li and Verkman 2001). AQP4 site-specific anchoring and localization is dependent upon $\alpha$-syntrophin (Neely et al. 2001), and defects in $\alpha$-syntrophin are associated with AQP4 dysfunction (Amiry-Moghaddam et al. 2003, 2004).

AQP6 co-localizes with $\mathrm{H}^{+}$ATPase in the acid-secreting intercalated cells in the renal collecting ducts, and its expression is regulated by acid-base conditions (Promeneur et al. 2000; Yasui et al. 1999); it may function as a nitrate channel (Ikeda et al. 2002). Immunoreactivity for AQP6 has been localized to the sub-apical vestibular supporting cell cytoplasm in the human inner ear (Lopez et al. 2007) and in the mice and rat (Perin et al. 2010; Taguchi et al. 2008). To our knowledge, an AQP6 knockout mouse is not available, and the role of AQP6 in the inner ear is unknown. In the inner ear, protons need to be actively secreted into the endolymph in the cochlea in order to maintain a $\mathrm{pH}$ of 7.4 , because of the strongly positive potential of the endolymph $(+80 \mathrm{mV})$; thus, AQP6 may be involved acid-base homeostasis, as there is a constant passive efflux of protons from the endolymph (Beitz et al. 2003; Taguchi et al. 2008).

In addition to AQPs, other pathways for water transport include that via co-transporters such as the $\mathrm{Na}^{+} \mathrm{K}^{+} 2 \mathrm{Cl}$ cotransporter (NKCC) (Zelenina et al. 2005; Russell 2000). In the cochlea, NKCC1 is located in marginal cells, in spiral ligament fibrocytes, and in the dark cells of the vestibule and Scarpa's ganglia (Delpire et al. 1999). Of note, NKCC1 knockout mice are deaf and exhibit balance disorders; histopathology reveals a collapse of the endolymphatic space (Delpire et al. 1999; Dixon et al. 1999; Flagella et al. 1999). Another ion channel, $\mathrm{Na}^{+} \mathrm{K}^{+} \mathrm{ATPase}$, is the predominant factor for maintaining the osmotic gradient across the plasma membrane by providing the force for water transport across AQPs, and its localization in the inner ear has been documented (Zelenina et al. 2005; Ross et al. 1982; Pitovski and Kerr 2002).

In the present study, we have investigated (1) the localization and mRNA expression of AQP1, 4, and 6 in the macula utriculi obtained from patients diagnosed with Meniere's disease, (2) the immunolocalization of proteins related to endolymphatic homeostasis, viz., $\mathrm{Na}^{+} \mathrm{K}^{+}$ATPase and NKCC1, and (3) the co-localization of $\alpha$ syntrophin with AQP4. The findings are compared with those from the macula utriculi obtained from acoustic neuroma patients and with those from utricles obtained at autopsy from subjects with documented normal hearing and balance. 


\section{Materials and methods}

Specimens The Institutional Review Board (IRB) of UCLA approved this study. Appropriate informed consent was obtained from each patient before inclusion in the investigation. The temporal bones used in the present study are part of the Human Temporal Bone Consortium for Research Resource Enhancement funded by the National Institutes of Health (NIH), National Institute on Deafness and Other Communication Disorders (NIDCD).

Utricular maculae were surgically obtained from patients who had with intractable Meniere's disease and who had elected to undergo transmastoid labyrinthectomy. All patients had recurrent vertigo spells, despite medical management, and had non-functional hearing in the operated ear. All patients met the 1995 AAO-HNS criteria for definite Meniere's disease (Committee on Hearing and Equilibrium 1995). Utricular maculae obtained from patients with acoustic neuroma that required the translabyrinthine approach for resection were also used. Human temporal bone specimens were obtained post-mortem from six subjects with a history documenting a lack of auditory or vestibular symptoms ( 3 female and 3 male, age ranging from 83 to 97 years old, average age: 87). Post-mortem time ranged from 4 to $9 \mathrm{~h}$, with an average of $6.8 \mathrm{~h}$. The six patients with Meniere's disease ( 2 female and 4 male) had ages ranging from 66 to 84 years old (average age: 76). The six patients with acoustic neuroma ( 3 female and 3 male) were aged $41-73$ years old (average age: 49 ).

Tissue processing for immunohistochemistry Immediately after removal at surgery (Meniere's disease and acoustic neuroma specimens) and microdissection (autopsy), the vestibular endorgans were immersed in $4 \%$ paraformaldehyde in sodium phosphate buffer (0.11 M, pH 7.4) and kept in this solution for 12-24 h. Thereafter, the fixative was removed, and the utricles were washed with phosphatebuffered saline solution (PBS; 0.1 M, pH 7.2).

Cryoprotection and sectioning Utricular endorgans from surgery or autopsy were immersed first in sucrose $30 \%$ (in PBS) for 3 days and then embedded in Tissue Tek (O. C.T. compound, Polysciences, Warrington, Pa., USA). Before sectioning, the utricles were placed on Teflonembedding molds filled with Tissue Tek and properly oriented under the dissecting microscope to obtain longitudinal sections by using the nerve stump of the macula as reference. Cryostat serial sections $(12 \mu \mathrm{m})$ were obtained by using a Microm-HM550 Cryostat. The sections were mounted on Superfrost Plus glass slides (Fisher Scientific, Pittsburgh, Pa., USA) and stored at $-80^{\circ} \mathrm{C}$ until used.
Immunofluorescence staining Cryostat sections were rehydrated with PBS for $10 \mathrm{~min}$ and incubated at room temperature for $1 \mathrm{~h}$ with a blocking solution containing $1 \%$ bovine serum albumin fraction-V (Sigma, St. Louis, Mo., USA), 1\% Triton X-100 (Sigma) in PBS. Next, the solution was removed, and the tissue sections were incubated with the primary polyclonal antibodies (raised in rabbit) against AQP1 and 6 (1:500 in PBS; from Alpha Diagnostic International [ADI], Tex., USA). Rabbit polyclonal antibodies against AQP4 (1:500 ADI, Tex. or 1:1000 from Santa Cruz, Calif., USA) were used. Tissue sections were incubated overnight at $4^{\circ} \mathrm{C}$ in a humid chamber. The secondary antibodies (against rabbit) labeled with Alexa 594 (1:1000 in PBS; Invitrogen, Carlsbad, Calif., USA) were applied and incubated for $1 \mathrm{~h}$ at room temperature in the dark. At the end of the incubation, sections were washed with PBS, and phalloidin Oregon green (1:50 in PBS; Invitrogen) was applied for $5 \mathrm{~min}$. Tissue sections were washed again with PBS and covered with a water-soluble mounting media (Vectashield, Vector Labs, Burlingame, Calif., USA).

Macula utriculi sections were immunoreacted with the following antibodies: mouse monoclonal antibodies against the $\alpha 5$ subunit of the $\mathrm{Na}^{+} \mathrm{K}^{+}$ATPase (1:500, Hybridoma Bank, University of Iowa, Iowa, USA), rabbit polyclonal affinity purified antibodies against NKCC1 (1:1000, ADI, Texas), $\alpha$-syntrophin (1:1000, Abcam, Cambridge, Mass., USA), and myosin VIIa (1:500, Abcam). For co-localization, a mixture of polyclonal and monoclonal antibodies was applied: myosin VII with $\mathrm{Na}^{+} \mathrm{K}^{+}$ATPase or NKCC1 with $\mathrm{Na}^{+} \mathrm{K}^{+}$ATPase.

Immunohistochemical controls As positive controls, cryostat sections from human kidney (AQP4 and AQP6) and human red blood cells (AQP1), and human, rat, and mouse inner ear were incubated with AQP antibodies. Kidney and inner ear tissue and sections from rats were processed in an identical fashion as human utricular sections with regard to fixation time, embedding, sectioning, and immunostaining. Normal human kidney frozen sections were acquired from the Bio-chain Institute (Hayward, Calif., USA). These sections were fixed with $2 \%$ paraformaldehyde for $5 \mathrm{~min}$ prior to immunofluorescence staining.

As negative controls, utricular macula cryostat sections obtained from surgery or autopsy were immunohistochemically stained without the primary antibody or with antibodies that had been pre-absorbed with the corresponding blocking peptide used to generate the antibody. Antibody absorption was made by incubating the primary antibody with the blocking peptide (at $1 \mu \mathrm{g} / 1 \mu \mathrm{g}$ ). The mixture was then placed at $37^{\circ} \mathrm{C}$ for $1 \mathrm{~h}$, after which immunohistochemical staining was performed as described above. In 
both cases, only a faint background in human utricular sections was observed. The cross-reactivities of the AQP antibodies have been previously described in detail (Lopez et al. 2007).

Image acquisition Immunostained tissue sections were viewed and imaged with an Olympus BX51 fluorescent microscope (Olympus America, N.Y., USA) equipped with an Olympus DP70 digital camera. To provide unbiased comparisons of the immunoreactive signal between each specimen, all images were captured by using strictly the same camera settings. Images were acquired by means of MicroSuite Five software (Olympus America). All images were prepared with the Adobe Photoshop software program run on a Dell Precision 380 computer. This program was used to optimize brightness and contrast. The image content was neither enhanced nor changed. To analyze for an effect of optimization of the photomicrograph image, quantitative analysis was conducted before and after optimization. Differences in measurements were not significantly different before and after optimization $(P=0.646)$. No further modifications to the image were made for the quantitative analysis.

Quantification of immunostained areas For quantitative immunocytochemistry, macula utriculi cryosections obtained from Meniere's disease, acoustic neuroma, or normative post-mortem patients were simultaneously immunoreacted with the same batch of antibodies and buffers, and the antigen-antibody reaction was stopped at the same time. To minimize bias in the analysis, the observer was "blinded" to the identity of the tissue samples to be analyzed. A second person not blinded to the sample identity, coded each sample. To determine the possible presence of regional variations in the immunostaining pattern, cryostat serial cross sections were made of the whole utricle. One section (separated every $200 \mu \mathrm{m}$ ) was immunostained for a specific marker and used for image observation and analysis. Observations from the periphery, intermediate, and central portions of the epithelia were made at low magnification $(\times 100$ and $\times 200)$. Image acquisition and analyses were made on micrographs acquired at $\times 400$. The immunostained area for each AQP, $\mathrm{Na}^{+} \mathrm{K}^{+}$ATPase, NKCC1, and syntrophin was measured in these three different regions of the sensory epithelia.

The area immunostained in utricular macula sections was quantified by using the computer image analysis software ImageJ (available free over the Internet: http:// rsb.info.nih.gov/ij/index.html) with the protocol described by Rangan and Tesch (2007). The digital image (captured as described above) was opened by using ImageJ program and converted to grayscale (Image/Type/8-bit). The threshold for staining detection was set by selecting (Image/
Adjust/Threshold), and the threshold level was adjusted. The image was then converted to binary (black and white). The immunostained area of interest was defined by using the polygon tool. To determine the area stained within the region of interest, Analyze/Analyze Particles was selected on the tool bar, the "Masks" tool was selected from the menu, and a summary of results appeared showing the total area that was immunostained within the region of interest.

Statistical analysis For each specimen, mean values of the immunostained area were averaged and subjected to oneway repeated measures analysis of variance. Six utricles per type of specimen were used for quantification (total: 18). Comparisons were made between the three types of specimen: Meniere's disease vs. acoustic neuroma, Meniere's disease vs. normative post-mortem, and acoustic neuroma vs. normative post-mortem. Values were considered statistically significant at $P \leq 0.05$. Results were expressed as the percentage from the "control" utricles obtained for autopsy. The Sigma Stat 3.1 software program (Sigma Stat, Ashburn, Va., USA) was used for statistical analysis.

Considerations on the use of vestibular endorgans obtained from autopsy and surgery for quantitative immunohistochemistry Autolytic artifact secondary to fixation delay is unavoidable in human material. This effect is especially critical for examination by cytochemical techniques. To minimize post-mortem artifacts, we used temporal bones harvested between 3 and $9 \mathrm{~h}$ post-mortem. We selected specimens with a minimum degree of swollen calyces and autolysis (Ishiyama et al. 2009; Lopez et al. 2007). The quality of the microdissected endorgan tissue sections was further confirmed by staining with hematoxylin and eosin. In general, shorter post-mortem times were associated with better signal and a lower background. No effect of increasing age was seen with respect to the quality of immunoreactivity. The time of harvesting and fixation time for surgical specimens, i.e., Meniere's disease and acoustic neuroma, were better controlled. In the surgical cases, upon surgical extraction, tissue was immediately transported to the laboratory, and specimens were post-fixed for $24 \mathrm{~h}$. In the case of post-mortem specimens, we found it much more difficult to control post-mortem time. By selecting specimens with a minimum degree of swollen calyces, we minimized post-mortem changes.

Real-time reverse transcription with polymerase chain reaction

Specimens Surgically acquired utricular maculae from patients with Meniere's disease ( 2 male and 1 female, aged 63,68 , and 86 years) or acoustic neuroma ( 1 male and 2 
female, aged 34, 44, and 57 years) were received in RNAlater (Ambion, Texas, USA) and taken immediately to the laboratory. Samples were placed overnight in the refrigerator at $4^{\circ} \mathrm{C}$. The following day, the vials containing the specimens were placed at $-80^{\circ} \mathrm{C}$ until the mRNA was extracted.

Nucleotide sequence primer design AQP primers were designed and validated by using mRNA from normal human kidney (Ambion); for AQP1: forward GTAGCCCTTGGA CACCTC; reverse AGCCAAAGGACCGAGCAG (accession number NM198098.1); for AQP4: forward GGAGCAG GAATCCTCTATC; reverse AGACCATGACCAGCGGTA (accession number NM001650.4); for AQP6: forward CATTGGGAAGTTCACAGTCCA; reverse CGAAGTTG TAGATCAGTGAGGC (accession number NM001652.3); for the housekeeping gene D-glyceraldehyde-3-phosphate dehydrogenase (GADPH): forward ACAACTTTGGT ATCGTGGAA; reverse (accession number NM002046.3). Each mRNA sequence was aligned with its corresponding genomic sequence by using the BLAST application (NCBI) to determine exon-intron boundaries. Every effort was made to identify a prime pair that spanned an intron. This step minimized the chance of amplifying a product from genomic DNA contamination of the RNA sample. Each primer was compared with the entire non-redundant GenBank nucleotide database by using the BLAST application (NCBI) to ensure that it recognized only the gene of interest. All primers were synthesized by Invitrogen.

RNA extraction and reverse transcription Total RNA was extracted from each utricle by using TRIzol Reagent (Invitrogene) as described by Lopez et al. (2009).

For reverse transcription (RT) of total RNA, the following solutions were added to approximately $3 \mu \mathrm{g}$ RNA: $10 \mu \mathrm{l}$ Mixmaster-buffered mRNA (final concentration of $1 \times$ ), $2 \mathrm{mM}$ Oligo $\mathrm{dT}, 1 \mathrm{ml}$ StrataScript, and nuclease-free $\mathrm{H}_{2} \mathrm{O}$ to give a total volume of $20 \mathrm{ml}$ per tube. We also prepared one "no-template control" tube contained $\mathrm{H}_{2} \mathrm{O}$ in place of RNA for each sample. Samples were incubated in the thermocycler and exposed to the following conditions: $25^{\circ} \mathrm{C}$ for $5 \mathrm{~min}, 42^{\circ} \mathrm{C}$ for $40 \mathrm{~min}$, and $95^{\circ} \mathrm{C}$ for $5 \mathrm{~min}$. The samples were stored at $-20^{\circ} \mathrm{C}$ until use.

Real-time polymerase chain reaction Amplification was performed with the single-color real-time polymerase chain reaction (PCR) system in a Stratagene Mx3000P. PCR tubes were prepared with $25 \mu \mathrm{l}$ real-time PCR consisting of $50 \mathrm{ng}$ cDNA, $12.5 \mu \mathrm{l} 2 \times \mathrm{SYBR}$ green PCR master mix (Superarray), $150 \mathrm{nM}$ primer mix, and nuclease-free $\mathrm{H}_{2} \mathrm{O}$ to a total volume of $25 \mathrm{ml}$ per tube. Thermal cycling conditions comprised an initial denaturation step at $95^{\circ} \mathrm{C}$ for $10 \mathrm{~min}, 40$ cycles at $95^{\circ} \mathrm{C}$ for $10 \mathrm{~s}, 60^{\circ} \mathrm{C}$ for $20 \mathrm{~s}$, and $72^{\circ} \mathrm{C}$ for $30 \mathrm{sc}$, followed by melting curves to display product dissociation characteristics. Each cDNA sample was evaluated for target genes of interest and a housekeeping gene. In addition, a no-template control sample was included for each primer set to verify that no reagents were contaminated with DNA, or that the primers did not produce signal by dimer formation. Primer sets were validated to ensure amplification of a single product with appropriate efficiency. Samples were run in duplicate, and the amplified products were analyzed by $4 \%$ agarose gel electrophoresis.

Data analysis The threshold cycle $\left(\mathrm{C}_{\mathrm{t}}\right)$ for each reaction (which is directly related to the amount of starting template in the reaction) was calculated within the exponential phase of the PCR by using Stratagene software MxPro V3. A correction was performed with a passive reference dye (Rox), which was present in the PCR master mix. Reactions with a $\mathrm{Ct}$ value 36 or with evidence of non-specificity (e.g., low melting temperatures or multiple peaks in melting point analysis) were excluded from the analysis. To correct for differences in both RNA quality and quantity between samples, data were normalized by using the housekeeping gene GADPH. The difference in $\mathrm{C}_{t}$ values $\left(\mathrm{DC}_{\mathrm{t}}\right)$ was then calculated for each gene by taking triplicate $C_{t}$ values from three reactions and subtracting the mean $C_{t}$ of the triplicates for the control gene (GADPH) for each cDNA sample at the same concentration. An additional difference in $\mathrm{DC}_{t}$ value $\left(\mathrm{DDC}_{\mathrm{t}}\right)$ was calculated for each gene by taking the triplicate $\mathrm{DC}_{\mathrm{t}}$ values for each gene in Meniere's specimens and subtracting the mean $\mathrm{DC}_{t}$ value of the triplicates for acoustic neuroma specimens. The relative expression level was calculated by using the $2^{-\mathrm{DDCt}}$ method (Livak and Schmittgen 2001). Because of the small number of Meniere's and acoustic neuroma specimens, only qualitative comparisons were made of the individual mRNA expression levels for each AQP.

\section{Results}

Immunohistochemical controls AQP1 immunoreactivity in the human proximal tubules of the kidney and in human red blood cells is shown in Fig. 1a, a'. The AQP1 immunostaining pattern is similar to that in previously published reports (Huang et al. 2002; Merves et al. 2005; Stankovic et al. 1995; Miyabe et al. 2002). Figure 1b demonstrates AQP4 immunoreactivity in a cross section of the rat organ of Corti; the inner sulcus and outer sulcus cells are AQP4immunoreactive. The AQP4 immunoreactivity in the rat collecting duct of the kidney presented in Fig. 1b' is also similar to that in previously published reports (Huang et al. 2002; Li and Verkman 2001; Mhatre et al. 2002; Miyabe 
Fig. 1 Immunohistochemical controls. a AQP1 immunoreactivity (red) in the human kidney. a' AQP1 immunoreactivity (red) in human red blood cells. AQP1 localizes on the membrane (arrowheads). b AQP4 immunoreactivity (red) in a cross section of the rat organ of Corti. Inner sulcus and outer sulcus cells are AQP4-immunoreactive (arrowheads). Phalloidin Oregon green staining was used to identify actin in the apical portion of supporting cells (green). b' AQP4 immunoreactivity in the rat kidney (amber) counterstained with hematoxylin (blue nuclei). c AQP6 immunoreactivity in the rat kidney (amber, arrows) counterstained with hematoxylin (purple nuclei). $\mathbf{d}$ Cross section of a human macula utriculi from an autopsy; AQP1 was absorbed with the corresponding peptide. No specific immunoreaction was detected. e $\mathrm{Na}^{+} \mathrm{K}^{+}$ATPase (red) in the rat stria vascularis $(S V)$ and spiral ligament $(s l)$. f $\mathrm{NKCC1}$ in the rat $\mathrm{SV}, \mathrm{sl}$, and spiral limbus (right; dark amber). $\mathbf{g} \alpha$-Syntrophin in blood vessels of the mice cerebellum (green). Bars $50 \mu \mathrm{m}(\mathbf{a}, \mathbf{b}, \mathbf{e}, \mathbf{f})$, $10 \mu \mathrm{m}$ (a'), $120 \mu \mathrm{m}$ (b'), $40 \mu \mathrm{m}$ (c), $45 \mu \mathrm{m}$ (d), $25 \mu \mathrm{m}(\mathrm{g})$
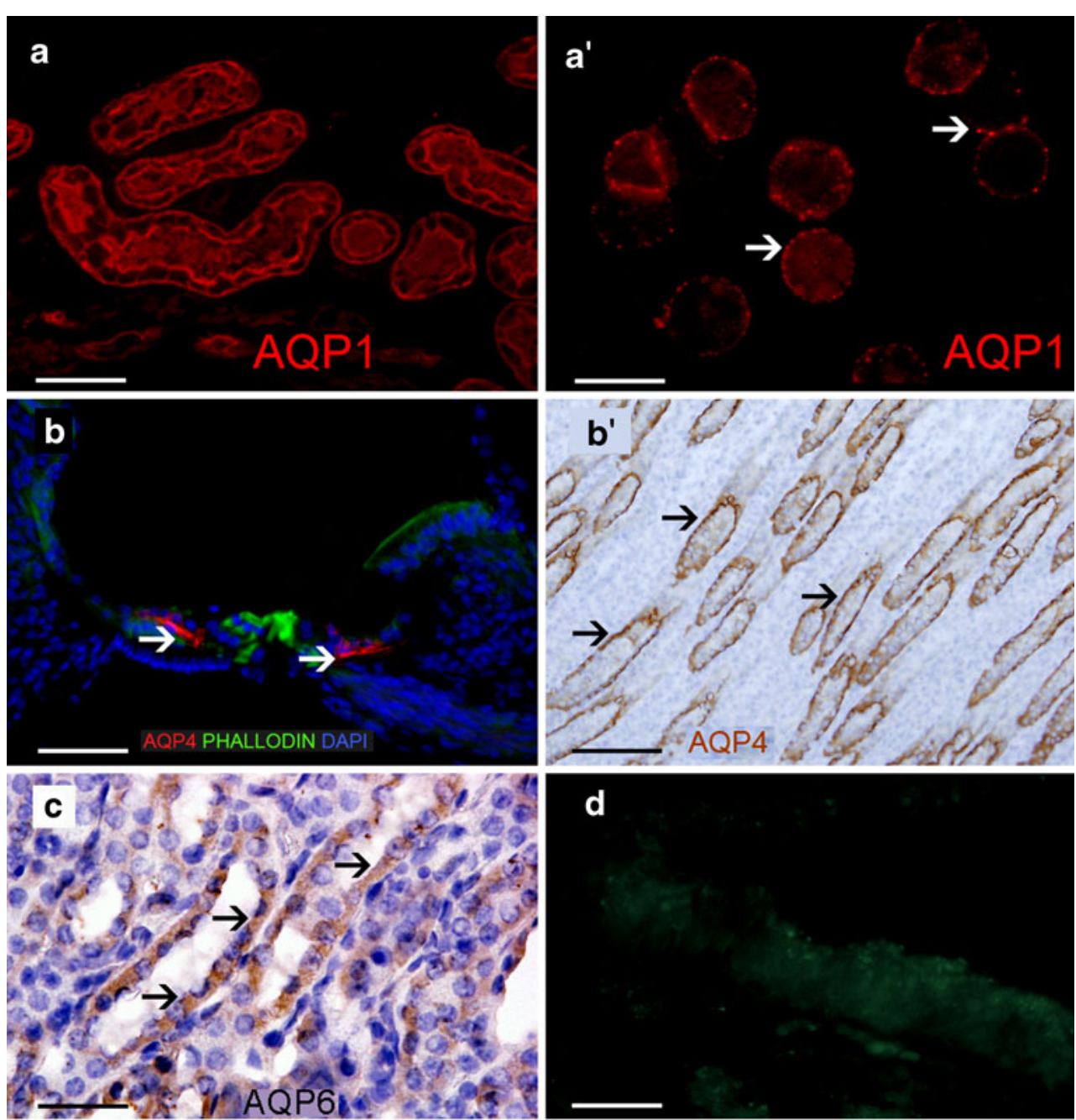

d
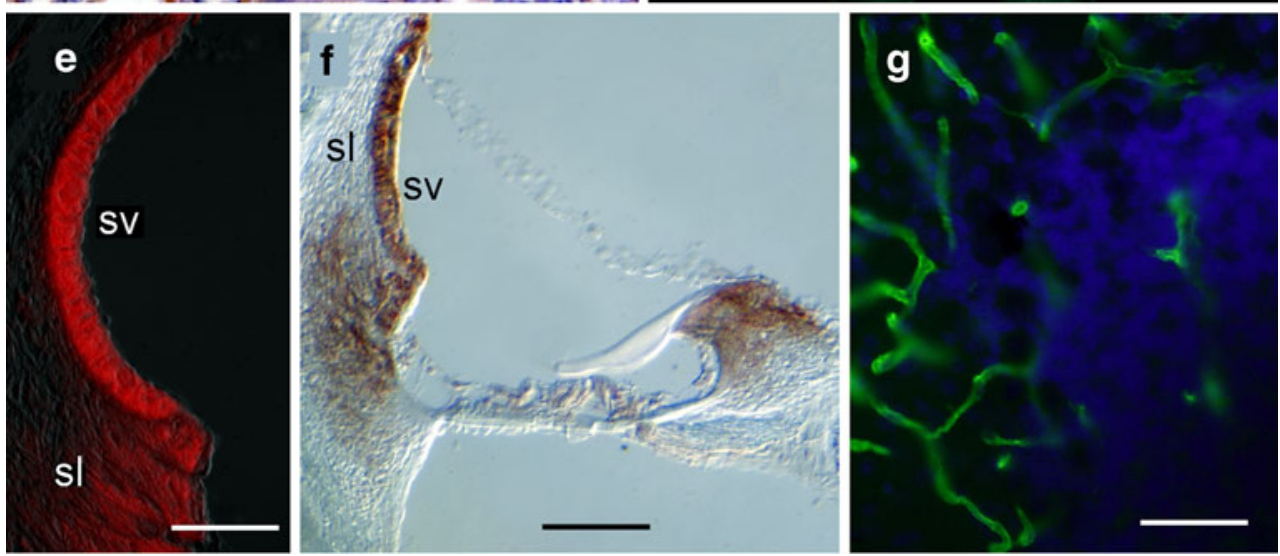

et al. 2002), as is the AQP6 immunoreactivity in the intercalated cells of the collecting duct of the rat kidney (Fig. 1c; Ohshiro et al. 2001). When the antibody against AQP4 is absorbed with the peptide used to generate the antibody, no signal is observed in the human macula utriculi (Fig. 1d; negative control). $\mathrm{Na}^{+} \mathrm{K}^{+}$ATPase immunoreactivity in the rat stria vascularis and spiral ligament (Fig. 1e) resembles that in previous studies (Ross et al. 1982; Pitovski and Kerr 2002), as does the NKCC1 immunostaining in the rat stria vascularis, spiral ligament, and spiral limbus (Fig. 1f; Delpire et al. 1999; Flagella et al. 1999; Crouch et al. 1997). Figure $1 \mathrm{~g}$ shows $\alpha$-syntrophin in blood vessels of the mouse cerebellum, as has been previously reported (Amiry-Moghaddam et al. 2003; Neely et al. 2001). 


\section{AQP1 immunolocalization}

AQP1 immunofluorescence in sections of the utricular maculae from Meniere's disease patients (Fig. 2a) was similar to that of acoustic neuroma (Fig. 2a') and normal postmortem subjects (Fig. 2a"). No changes were noted in the regional distribution of AQP1 within the epithelium in the utricular maculae from Meniere's patients. Immunoreactivity was seen within fibrocytes in the stroma underneath the sensory epithelia and within the trabecular perilymphatic tissue (Fig. 2a, a', a"). Quantitative immunofluorescence measurements for AQP1 showed no statistically significant differences between AQP1 immunoreactivity measurements from specimens from subjects with Meniere's disease compared with those from acoustic neuroma or autopsy subjects (Fig. 2a"”).

\section{AQP4 immunolocalization}

In specimens from Meniere's subjects, acoustic neuroma, and autopsy (Fig. 2b, b', b" respectively), AQP4 expression was localized to the basal portion of supporting cells in the utricular sensory epithelium. No changes were noted in the regional distribution of AQP4 within the epithelium in the utricular maculae from Meniere's patients, whereas a significant decrease of AQP4 immunoreactivity was seen in the utricular maculae from patients with Meniere's disease (Fig. 2b) when compared with those from patients with acoustic neuroma (Fig. 2b') and with autopsy specimens (Fig. 2b"). Quantitative immunofluorescence measurements confirmed a decrease (statistically significant) of AQP4 immunoreactivity in specimens from Meniere's subjects compared with acoustic neuroma and autopsy specimens (Fig. 2b"). Acoustic neuroma specimens showed no statistically significant alteration of AQP4 expression when compared with autopsy specimens.

\section{AQP6 immunolocalization}

AQP6 immunoreactivity was distributed throughout the cytoplasm of vestibular supporting cells, from basal to apical regions, in Meniere's specimens (Fig. 2c). In contrast, AQP6 immunoreactivity was polarized to the sub-apical vestibular supporting cell in acoustic neuroma specimens (Fig. 2c') and in autopsy specimens (Fig. 2c"). In all cases, vestibular hair cells, nerve fibers, stromal cells, and blood vessels were non-immunoreactive. AQP6 did not co-localize with phalloidin staining, corroborating the subapical intracellular localization of AQP6. Quantitative immunofluorescence measurements showed a significant increase of AQP6 immunoreactivity in utricular macula from patients with Meniere's disease when compared with those from acoustic neuroma patients and autopsy speci- mens (Fig. 2c"'). Acoustic neuroma specimens showed no statistically significant alteration of AQP6 expression when compared with autopsy specimens.

Immunolocalization of proteins related to ion homeostasis in the macula utriculi of Meniere's patients

NKCC1 immunoreactivity localized to the nerve fibers and calyces within the sensory epithelium of the macula utriculi in Meniere's specimens (Fig. 3a). $\mathrm{Na}^{+} \mathrm{K}^{+}$ATPase immunoreactivity showed a similar pattern of expression. Myosin VII immunoreactivity (Fig. 3b) was used to identify vestibular hair cells; nerve fibers terminals and calyces that surrounded the hair cells were immunoreactive for $\mathrm{Na}^{+} \mathrm{K}^{+}$ATPase. $\alpha$-Syntrophin immunoreactivity was found in hair cell cytoplasm, in the basal region of supporting cells, and in stromal cells in specimens from Meniere's specimens (Fig. 3c). Similar immunoreactive patterns for $\mathrm{Na}^{+} \mathrm{K}^{+}$ATPase, $\mathrm{NKCC} 1$, and $\alpha$-syntrophin were observed in autopsy specimens (not shown). Meniere's specimens showed no statistically significant alteration of $\mathrm{Na}^{+} \mathrm{K}^{+}$ATPase, NKCC1, or $\alpha$-syntrophin immunoreactivity when compared with autopsy specimens (Fig. 3d). Utricular sections from acoustic neuroma were not stained with these antibodies, the sensory epithelium being devoid of nerve calyces.

Quantification and identification and of AQPs isoforms by real-time RT-PCR

Isolated mRNA was subjected to real-time RT-PCR to detect the mRNA of AQP1, 4, and 6. A comparison of $\mathrm{AQP} 1,4$, and 6 mRNA expression levels between Meniere's and acoustic neuroma specimens showed no differences (Fig. 4a). Electrophoresis examination of AQP mRNA amplification revealed that PCR yielded only one band for each AQP at the expected size (Fig. 4b).

\section{Discussion}

AQP1 immunolocalization and mRNA expression in Meniere's disease AQP1 and AQP4 immunolocalization in the human inner ear is highly conserved across species (Lopez et al. 2007; Beitz et al. 1999, 2003; Li and Verkman 2001; Merves et al. 2005; Mhatre et al. 2002; Stankovic et al. 1995; Takumi et al. 1998) indicative of their having an important role in the inner ear. In the present study, AQP1 immunolocalization in the utricular maculae acquired from patients with Meniere's disease is similar to that in acoustic neuroma and autopsy specimens; AQP1 is localized within the fibrocytes in the underlying stromal tissue and blood vessels. In a recent study, an alteration in AQP1 expression 
aqp1
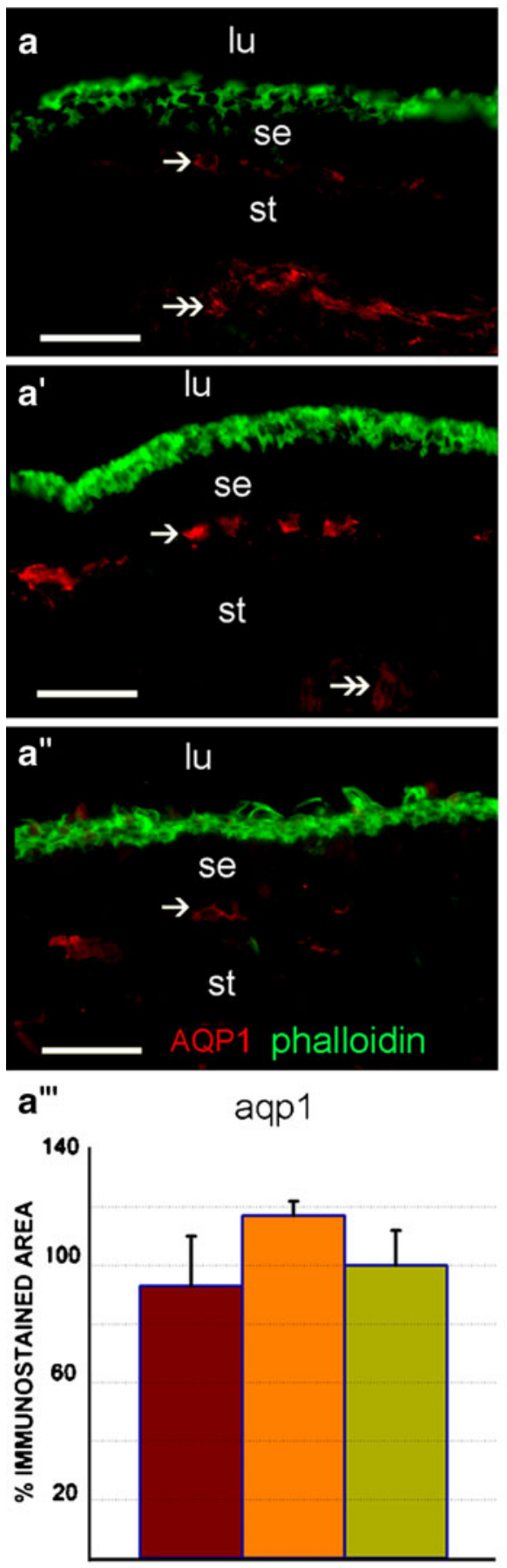

Menieres disease aqp4
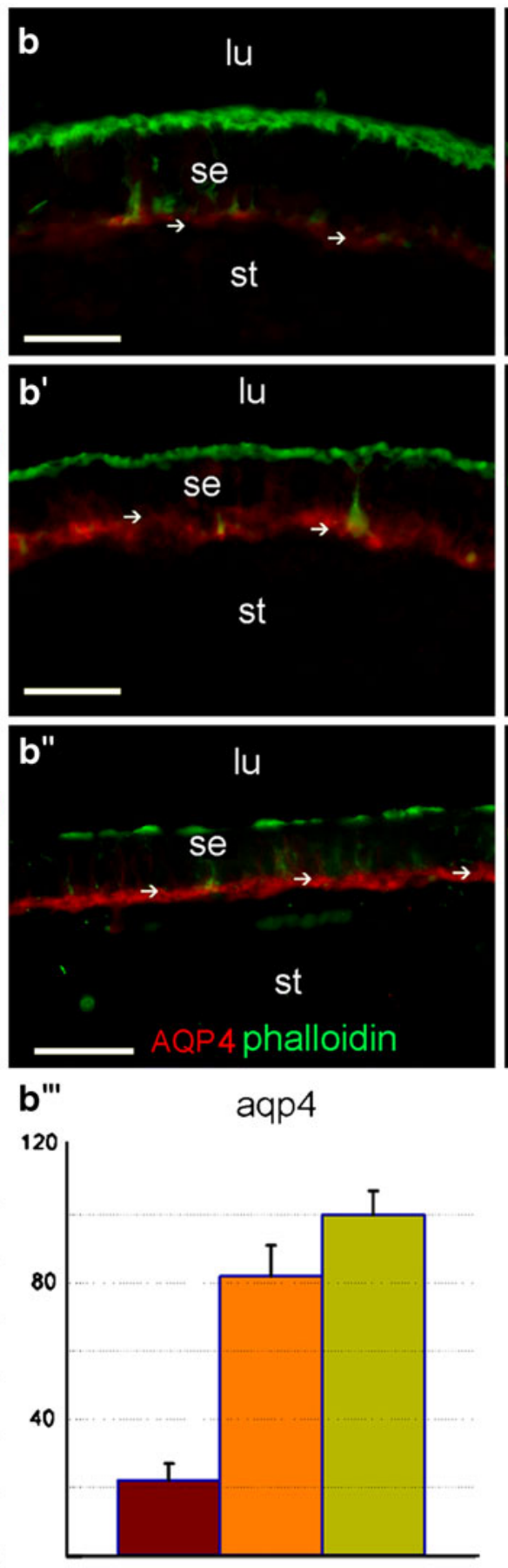

Acoustic neuroma aqp6
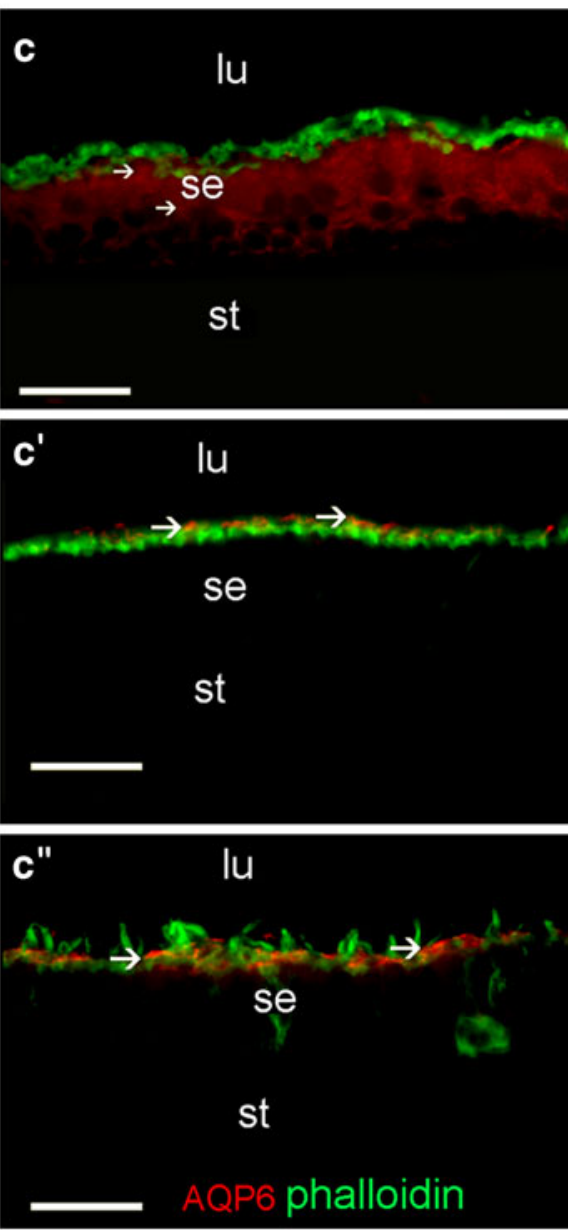

c"'

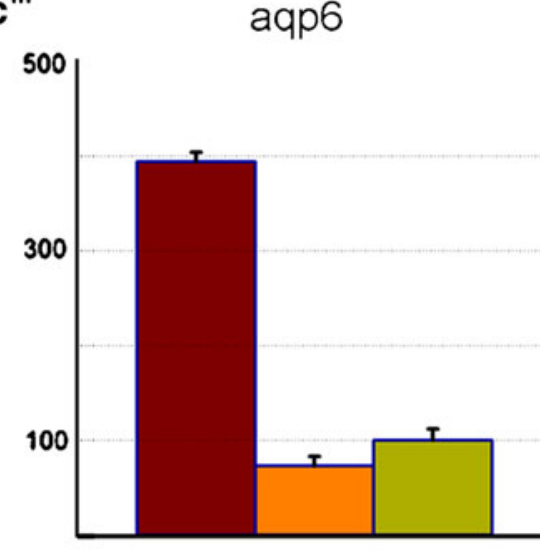

Autopsy appears to mediate the response to corticosteroids in cerebral edema (Tran et al. 2009), and intratympanic dexamethasone has been shown to be effective in the treatment of Meniere's disease (Boleas-Aguirre et al. 2007). mRNA expression for AQP1 isoforms has also been detected by RT-PCR, with no differences being found between the AQP1 mRNA expression in specimens from Meniere's subjects compared with those from acoustic neuroma. This lack of differences in the levels of mRNA expression between specimens from patients with Meniere's disease vs. acoustic neuroma must be interpreted with caution, given the small sample of patients analyzed. 
4 Fig. 2 AQP 1 (aqpl), AQP4 (aqp4), and AQP6 (aqp6) immunoreactivity in the utricular macula of Meniere's, acoustic, and autopsy patients. AQP1 immunoreactivity (red) in Meniere's disease (a), acoustic neuroma (a'), and autopsy specimens (a") is localized to the fibrocytes beneath the overlying sensory epithelium (se, arrow) and to the fibrocytes in the underlying stroma (st, double arrows) in the utricular maculae ( $l u$ luminal region). AQP1 immunoreactivity was not present in the sensory epithelium itself. A quantitative comparison of AQP1 immunoreactivity between the three types of specimens (a"') showed no statistically significant differences. AQP4 immunoreactivity (red) in Meniere's disease (b), acoustic neuroma (b'), and autopsy specimens (b") was localized to the basal pole of supporting cells. The AQP4 immunoreactivity in the utricular macula from subjects with Meniere's disease (b) was significantly diminished in the sensory epithelium (arrows) when compared with that in acoustic neuroma (b', arrows) and in autopsy material (b", arrows). Quantitative immunoreactivity analysis (b"') shows a statistically significant decrease in AQP4 immunoreactivity in Meniere's specimens when compared with acoustic neuroma and autopsy specimens. AQP6 immunoreactivity in Meniere's disease (c), acoustic neuroma (c'), and autopsy specimens (c"). In the utricular macula from subjects with Meniere's disease (c), AQP6 immunoreactivity (red) was diffusely distributed throughout the supporting cell in the sensory epithelium (arrows). In utricular maculae from patients with acoustic neuroma (c') and normative subjects (c"), AQP6 immunoreactivity was polarized to the sub-apical portion of the supporting cells. An increased intensity and more diffuse expression of AQP6 (red) was noted in Meniere's disease (c) compared with acoustic neuroma (c') and normative (c") material. Quantitative immunoreactivity analysis (c"') shows a statistically significant increase in AQP6 immunoreactivity in Meniere's specimens when compared with acoustic neuroma and autopsy specimens. Phalloidin Oregon green staining (green) was used to identify actin at the apical portion of the sensory epithelium. No co-localization was observed between AQP6 (red) and phalloidin (green) corroborating a sub-apical distribution in the supporting cell of utricular maculae derived from acoustic neuroma (b) and normative (c) samples. Bars $50 \mu \mathrm{m}(\mathbf{a}-\mathbf{a} ", \mathbf{b}-\mathbf{b} ", \mathbf{c}-\mathbf{c} ")$

Additionally, acoustic neuroma vestibular endorgans are pathological specimens and thus are not true "normative" specimens.

AQP4 immunolocalization and mRNA expression in Meniere's disease AQP4 expression was significantly diminished in vestibular endorgans from patients with Meniere's disease when compared with specimens from subjects with acoustic neuroma (surgical) and autopsy samples. In the normal human vestibular neuroepithelium, AQP4 has been localized to the basal pole of supporting cells (Lopez et al. 2007), and vestibular supporting cells have been hypothesized to play an important role in ionic and water homeostasis, similar to astroglial cells in the brain (Takumi et al. 1998). The decrease in AQP4 immunoreactivity in Meniere's specimens suggests a primary or secondary effect on water transport in Meniere's disease. A recent study on a mouse model for age-related hearing loss has demonstrated decreased AQP4 expression in the cochlea with increasing age (Christensen et al. 2009). The AQP4 knockout mouse (-/-) exhibits significant hearing loss but no visible morphological damage or endolymphatic hydrops ( $\mathrm{Li}$ and Verkman 2001; Mhatre et al. 2002). Moreover, in the human vestibular epithelium, the immunolocalization of AQP4 is intimately intertwined with the expression of the basement membrane protein, $\alpha$ dystroglycan, in normal post-mortem macula utricle, saccule, and cristae (Ishiyama et al. 2009). This interaction between the basement membrane protein, $\alpha$-dystroglycan, and AQP4, might be affected by the thickening of the basement membrane observed in vestibular endorgans from patients with intractable Meniere's disease, a finding highly correlated with vestibular neuroepithelial degeneration (McCall et al. 2009). Vacuolization of the supporting cell cytoplasm in the macula utriculi and crista obtained at surgery from Meniere's disease patients has also been noted. We have also detected mRNA for AQP4 isoforms by RT-PCR; however, no differences have been seen between the AQP4 mRNA expression in specimens from Meniere's subjects compared with those from acoustic neuroma. Again, this absence of differences must be interpreted with caution, given the small sample analyzed, and acoustic neuroma vestibular endorgans are pathological specimens and should not be considered as true "normative" specimens.

AQP6 immunolocalization and mRNA expression in Meniere's disease In specimens from patients with Meniere's disease, AQP6 expression was distributed throughout the supporting cell cytoplasm and demonstrated a significantly increased expression when compared with specimens from subjects with acoustic neuroma (surgical) and autopsy specimens. AQP6 expression was polarized to the sub-apical region of the supporting cells of the normative post-mortem subjects in the present study and in a previous study (Lopez et al. 2007) and in vestibular endorgans acquired from patients with acoustic neuroma. In a study of AQP6 protein and mRNA expression in the rat inner ear and endolymphatic sac, AQP6 was localized to the membrane of intracellular vesicles (Taguchi et al. 2008). Light- and electronmicroscopic examination of vestibular endorgans acquired from patients with intractable Meniere's disease demonstrated an abundance of vesicles in the vestibular supporting cells (McCall et al. 2009); this might have been related to the alterations in AQP4 and AQP6 expression in the supporting cells. The increased expression of AQP6 may reflect an altered acid-base balance in the inner ear of Meniere's disease. Studies have demonstrated that AQP6 is markedly upregulated in rats made chronically alkalotic with bicarbonate, indicating acid-base modulation (Promeneur et al. 2000). Alternatively, AQP6 may act as a nitrate channel. Nitrate is an endogenous oxide of nitrogen produced by nitric-oxide synthase in response to various stimuli and is toxic in vivo (Vatassery et al. 2004); recent studies have demonstrated the possible involvement of nitric oxide in response to oxidative stress in the inner ear (Ruan 
Fig. 3 Immunohistochemical localization of protein related to ion homeostasis in Meniere's disease patients. a Immunoreactivity for $\mathrm{Na}^{+} \mathrm{K}^{+}$ATPase (green) and $\mathrm{NKCC1}$ (red) is similarly located (double arrows; lu lumen, st stroma, se sensory epithelium). $\mathbf{b ~} \mathrm{Na}^{+} \mathrm{K}^{+}$ATPase in nerve fibers terminals and calyces (arrows). Co-localization with myosin VIIa (red) helps to visualize the cytoplasm of vestibular hair cells $(h c)$. c $\alpha$-Syntrophin shows a ubiquitous distribution in the sensory epithelium. Hair cell $(h c)$ cytoplasm (arrows) and the basal portion of supporting cells (sc, double arrowheads) are syntrophin immunoreactive. d Quantitative comparison of $\mathrm{Na}^{+} \mathrm{K}^{+}$ATPase, $\mathrm{NKCC} 1$, and syntrophin immunoreactivity between autopsy and Meniere's specimens reveals no statistically significant changes. Bars $26 \mu \mathrm{m}(\mathbf{a}, \mathbf{b}), 28 \mu \mathrm{m}(\mathbf{c})$
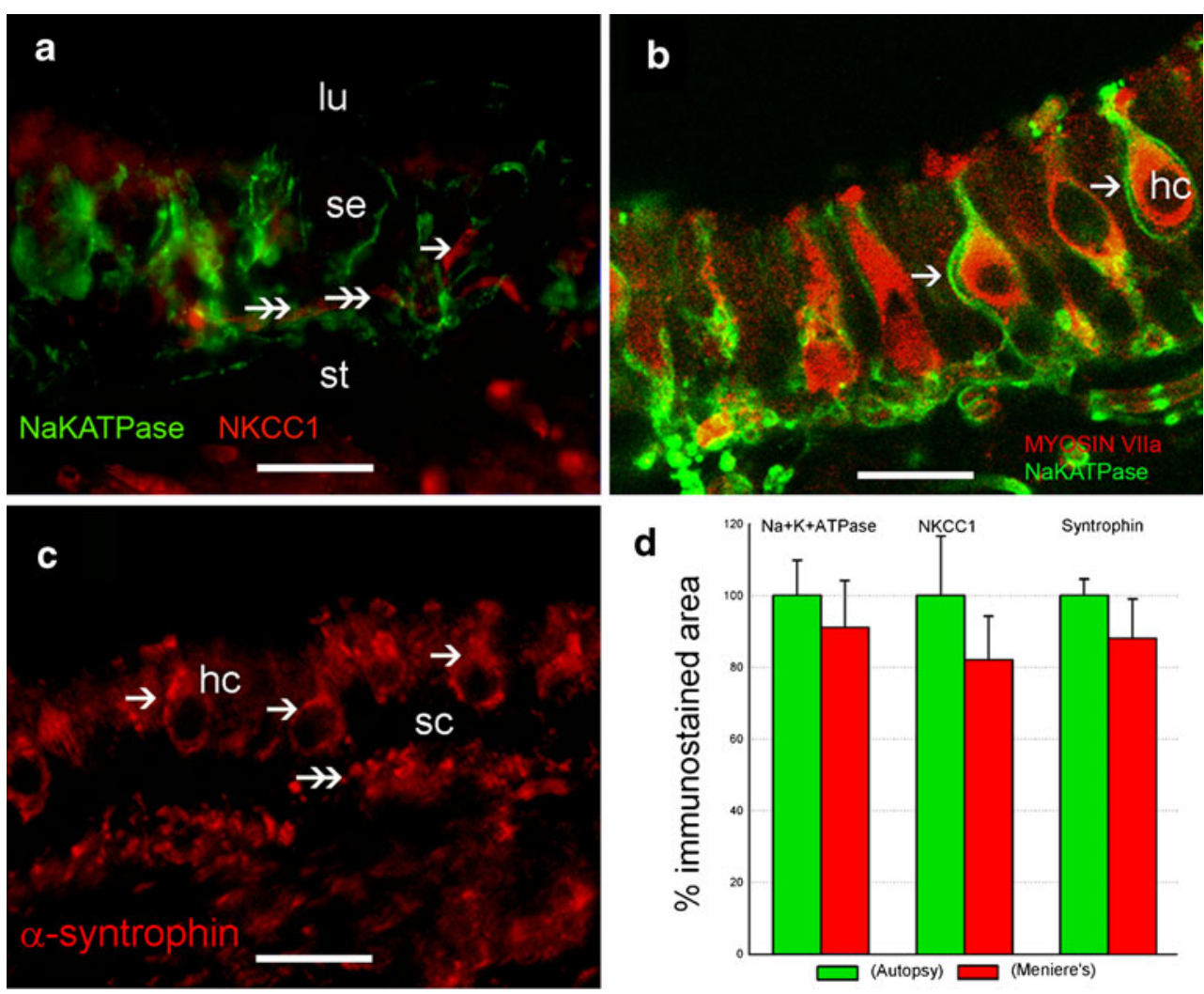

2002). The same caveat as that for AQP1 and AQP4 is also applicable here with respect to the lack of differences in the levels of AQP6 mRNA expression between specimens from patients with Meniere's disease vs. acoustic neuroma, given the small sample analyzed, and again, acoustic neuroma vestibular endorgans are pathological specimens and thus are not a true "normative" specimens.

Proteins involved in water, ion transport, and endolymph production We have localized NKCC1 immunoreactivity to the afferent calyceal nerve terminals of the sensory epithelia of utricular maculae. The NKCC1 co-transporter localizes to the basolateral membrane of dark cells and fibrocytes underlying the sensory epithelium and vestibular ganglia neurons similar to that in mice and gerbil (Delpire et al. 1999; Crouch et al. 1997). Because of the localization of NKCC1 in cellular components known for their production of endolymph, and because of the knowledge that knockout mice exhibit a collapse of the endolymphatic space (Delpire et al. 1999; Dixon et al. 1999; Flagella et al. 1999), we had a

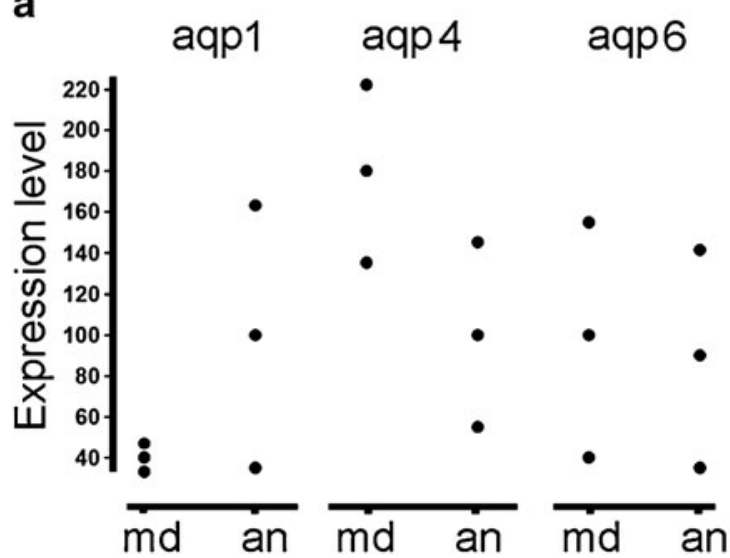

b $\quad \begin{array}{llll}1 & 4 & 6 & \mathrm{~m}\end{array}$

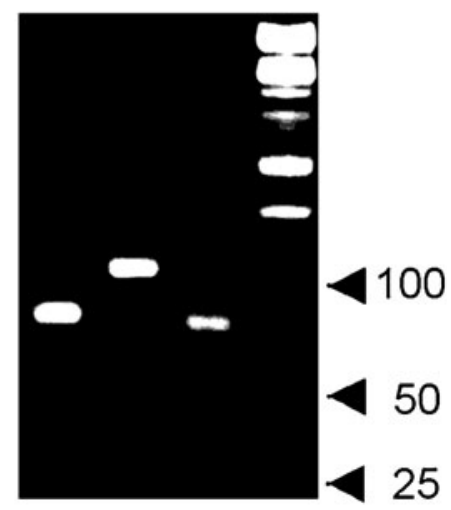

Fig. 4 Quantification by real-time reverse transcription with the polymerase chain reaction (PCR) of AQP mRNAs extracted from Meniere's and acoustic neuroma utricles. a Individual mRNA expression in utricles from subjects with Meniere's disease $(m d)$ and acoustic neuroma (an) patients. b Electrophoresis of real-time PCR products of AQP1 (1), AQP4 (4), and AQP6 (6) amplified from Meniere's utricle. Molecular size markers $(\mathrm{m})$ are indicated (ladder amplicon sizes of $100 \mathrm{bp}, 50 \mathrm{bp}$, and $25 \mathrm{bp}$ ) 
hypothesized that NKCC1 expression might be altered in Meniere's disease. However, in contrast to AQP4 and AQP6, no alteration has been seen in the distribution or intensity of the NKCC1 co-transporter expression in utricular maculae from patients with Meniere's disease compared with autopsy specimens.

$\mathrm{Na}^{+} \mathrm{K}^{+}$ATPase is expressed in nerve calyces that surround type I hair cells and in the basolateral membrane of transitional cells and dark cells with a similar expression between specimens from Meniere's patients and autopsy. We have detected mRNA transcripts for $\mathrm{Na}^{+} \mathrm{K}^{+}$ATPase in surgically acquired utricles from patients with Meniere's disease and acoustic neuroma; the diminished expression of $\mathrm{Na}^{+} \mathrm{K}^{+}$ATPase mRNA in acoustic neuroma is likely to be secondary to the loss of calyceal endings (Beltran-Parrazal et al. 2008). In the present study, we have also demonstrated syntrophin immunolocalization ubiquitously in the sensory epithelium and the underlying stroma with no apparent alteration in expression in utricular maculae acquired from Meniere's patients compared with those from autopsy specimens. Syntrophin co-localizes with AQP4 in both utricular maculae from post-mortem normative individuals and in Meniere's disease, and no immunohistochemical evidence has been obtained for an alteration in syntrophin to account for the diminished expression of AQP4 in the vestibular endorgans acquired from patients with Meniere's disease.

The role of AQP6 in the inner ear is unknown. However, in the renal system, AQP6 co-localizes with $\mathrm{H}^{+}$-ATPase in intracellular vesicles of acid-secreting alpha-intercalated cells (Yasui et al. 1999). Vacuolar $\mathrm{H}^{+}$-ATPase expression is dependent on regulation by the forkhead transcription factor Foxil in the kidney and the inner ear (Vidarsson et al. 2009). Under normal conditions, both proteins are localized in the sub-apical portion of epithelial cells; therefore, AQP6 in the vestibular supporting cells probably co-localizes with $\mathrm{H}^{+}$ATPase, which is expressed in cochlear supporting cells and the vestibular neuroepithelium (Stankovic et al. 1997). Thus, the altered expression of AQP4 and AQP6 may reflect or induce a disturbance in fluid and ion homeostasis in Meniere's disease.

An association of the inner ear aquaporins probably occurs with ephrins (Eph) and their receptors. The EphB2 receptor tyrosine kinase, a receptor that belongs to a group of molecules that control contact-mediated axon repulsion, may regulate ionic homeostasis and endolymph fluid production through macromolecular association with membrane channels that transport chloride, bicarbonate, and water (Cowan et al. 2000; Dravis et al. 2007). Ephrin-B2 is expressed in the vestibular supporting cells, and the knockout mouse exhibits abnormal $\mathrm{K}^{+}$concentrations in the endolymph and diminished endolymph production (Dravis et al. 2007). EphB2 and AQP1 form a stable macromolecular complex through their ability to bind to an adaptor protein. Mice lacking EphB2 exhibit vestibular dysfunction (Cowan et al. 2000). AQP1 is present in blood vessels within the stromal tissue of the utricle and crista, and AQP4 and AQP6 are present in vestibular supporting cells, probably co-localizing with ephrin-B2.

Meniere's disease and aquaporins Detailed histopathological studies of vestibular endorgans from patients with Meniere's disease have demonstrated significant thickening of the basement membrane underlying the vestibular neuroepithelium (McCall et al. 2009). The abnormally thickened basement membrane is probably dysfunctional, a significant factor given that the inner ear basement membrane plays an important role in ionic and water homeostasis. Attacks of vertigo and tinnitus may occur when basement membrane dysfunction or damage causes ionic disequilibrium and neuroepithelial damage. Of note, all of the patients in this study exhibit stage 4 Meniere's disease, exhibiting profound deafness and intractable recurrent vertigo spells.

In conclusion, the altered expression of AQP4 and AQP6 in the supporting cells of endorgans acquired from patients with intractable Meniere's disease may play a role in the formation of endolymphatic hydrops and may be directly associated with neuroepithelial dysfunction.

Open Access This article is distributed under the terms of the Creative Commons Attribution Noncommercial License which permits any noncommercial use, distribution, and reproduction in any medium, provided the original author(s) and source are credited.

\section{References}

Agre P, Landon S, Masato Y, Guggino W, Ottersen O, Fujiyoshi Y, Engel A, Nielsen S (2002) Aquaporin water channels-from atomic structure to clinical medicine. J Physiol (Lond) 542:3-16

Amiry-Moghaddam M, Ottersen OP (2003) The molecular basis of water transport in the brain. Nat Rev Neurosci 4:991-1001

Amiry-Moghaddam M, Otsuka T, Hurn PD, Traystman RJ, Haug FM, Froehner SC, Adams ME, Neely JD, Agre P, Ottersen OP, Bhardwaj A (2003) An alpha-syntrophin-dependent pool of AQP4 in astroglial end-feet confers bidirectional water flow between blood and brain. Proc Natl Acad Sci USA 100:2106-2111

Amiry-Moghaddam M, Frydenlund DS, Ottersen OP (2004) Anchoring of aquaporin-4 in brain: molecular mechanisms and implications for the physiology and pathophysiology of water transport. Neuroscience 129:999-1010

Andrews JC (2004) Intralabyrinthine fluid dynamics: Meniere's disease. Curr Opin Otolaryngol Head Neck Surg 12:408-412

Baloh RW (2001) Prosper Meniere's and his disease. Arch Neurol 58:1151-1156

Beitz E, Kumagami H, Krippeit-Drews P, Ruppersberg JP, Schultz JE (1999) Expression pattern of aquaporin water channels in the inner ear of the rat: the molecular basis for a water regulation system in the endolymphatic sac. Hear Res 132:76-84

Beitz E, Zenner HP, Schultz JE (2003) Aquaporin-mediated fluid regulation in the inner ear. Cell Mol Neurobiol 23:315-329 
Beltran-Parrazal L, Lopez IA, Ishiyama G, Ishiyama A (2008) Ion channels transporters, cotransporters, and aquaporin gene profile expression in utricle of patients with Meniere's disease. In: Popelka GR (ed) Abstracts of 21st Midwinter Research Meeting. Association for Research in Otolaryngology, Mt. Royal, p243

Boassa D, Yool AJ (2002) A fascinating tail: cGMP activation of aquaporin-1 ion channels. Trends Pharmacol Sci 23:558-562

Boassa D, Stamer WD, Yool AJ (2006) Ion channels function of aquaporin-1 natively expressed in choroid plexus. J Neurosci 26:7811-7819

Boleas-Aguirre MS, Lin FR, Della Santina CC, Minor LB, Carey JP (2007) Longitudinal results with intratympanic dexamethasone in the treatment of Meniere's disease. Otol Neurotol 29:33-38

Committee on Hearing and Equilibrium (1995) Meniere's disease: criteria for diagnosis and evaluation of therapy for reporting. Otolaryngol Head Neck Surg 113:181-185

Cowan CA, Yokoyama N, Bianchi LM, Henkemeyer M, Fritzsch B (2000) EphB2 guides axons at the midline and is necessary for normal vestibular function. Neuron 26:417-430

Christensen N, D'Souza M, Zhu X, Frisina RD (2009) Age-related hearing loss: aquaporin 4 gene expression changes in the mouse cochlea and auditory midbrain. Brain Res 1253:27-34

Crouch JJ, Sakaguchi N, Lytle C, Schulte BA (1997) Immunohistochemical localization of the $\mathrm{Na}-\mathrm{K}-\mathrm{Cl}$ co-transporter $(\mathrm{NKCC} 1)$ in the gerbil inner ear. J Histochem Cytochem 45:773-778

Delpire E, Lu J, England R, Dull C, Thorne T (1999) Deafness and imbalance associated with inactivation of the secretory $\mathrm{Na}-\mathrm{K}-2 \mathrm{Cl}$ co-transporter. Nat Genet 22:192-195

Dixon MJ, Gazzard J, Chaudhry SS, Sampson N, Schulte BA, Stell KP (1999) Mutation of the Na-K-Cl co-transporter gene Slc12a2 results in deafness in mice. Hum Mol Genet 8:1579-1584

Dravis C, Wu T, Chumley MJ, Yokoyama N, Wei S, Wu DK, Marcus DC, Henkemeyer M (2007) EphB2 and ephrin-B2 regulate the ionic homeostasis of vestibular endolymph. Hear Res 223:93-104

Flagella M, Clarke LL, Miller ML, Erway LC, Giannella RA, Andringa A, Gawenis LR, Kramer J, Duffy JJ, Doetschman T, Lorenz JN, Yamoha EN, Cardell EL, Shull GE (1999) Mice lacking the basolateral Na-K-2Cl cotransporter have impaired epithelial chloride secretion and are profoundly deaf. J Biol Chem 274:26946-26955

Hallpike CS, Cairns H (1938) Observations on the pathology of Meniere's syndrome. J Laryngol Otol 53:625

Hibino H, Kurachi Y (2006) Molecular and physiological bases of the $\mathrm{K}^{+}$ circulation in the mammalian inner ear. Physiology 21:336-345

Huang D, Chen P, Chen S, Nagura M, Lim DJ, Lin X (2002) Expression patterns of aquaporins in the inner ear: evidence for concerted actions of multiple types of aquaporins to facilitate water transport in the cochlea. Hear Res 165:85-95

Ishiyama A, Mowry SE, Lopez IA, Ishiyama G (2009) Immunohistochemical distribution of basement membrane proteins in the human inner ear from older subjects. Hear Res 254:1-14

Ishiyama G, Lopez IA, Ishiyama A (2006) Aquaporins and Meniere's disease. Curr Opin Otolaryngol Head Neck Surg 14:332-336

Ikeda M, Beitz E, Kozono D, Guggino W, Agre P, Yasui M (2002) Characterization of aquaporin 6 as a nitrate channel in mammalian cells. J Biol Chem 277:39873-39879

Lang F, Vallon V, Knipper M, Wangemann P (2007) Functional significance of channels and transporters expressed in the inner ear and kidney. Am J Physiol Cell Physiol 293:1187-1208

Li J, Verkman AS (2001) Impaired hearing in mice lacking aquaporin4 water channels. J Biol Chem 276:31233-31237

Livak KJ, Schmittgen TD (2001) Analysis of relative gene expression data using real-time quantitative PCR and the 2-DDcT method. Methods 25:402-408

Lopez IA, Ishiyama G, Lee M, Baloh RW, Ishiyama A (2007) Immunohistochemical localization of aquaporins in the human inner ear. Cell Tissue Res 328:453-460
Lopez IA, Acuna D, Beltran-Parrazal L, Lopez IE, Amarnani A, Cortes M, Edmond J (2009) Evidence for oxidative stress in the developing cerebellum of the rat after chronic mild carbon monoxide exposure $(0.0025 \%$ in air). BMC Neurosci 10:53

Magni F, Sarto C, Ticozzi SD, Bosso N, Mocarelli P, Kienle MG (2006) Proteomic knowledge of human aquaporins. Proteomics 6:5637-5649

McCall AA, Ishiyama GP, Lopez IA, Bhuta S, Vetter S, Ishiyama A (2009) Histopathological and ultrastructural analysis of vestibular endorgans in Meniere's disease reveals basement membrane pathology. BMC Ear Nose Throat Disord 9:4

Merchant SN, Adams JC, Nadol JB Jr (2005) Pathophysiology of Meniere's syndrome: are symptoms caused by endolymphatic hydrops? Otol Neurotol 26:74-81

Merves M, Krane CM, Dou H, Greinwald JH, Menon AG, Choo D (2005) Expression of aquaporin 1 and 5 in the developing mouse inner ear and audiovestibular assessment of an AQP5 null mutant. J Assoc Res Otolaryngol 4:264-275

Mhatre AN, Stern RE, Li J, Lalwani AK (2002) Aquaporin 4 expression in the mammalian inner ear and its role in hearing. Biochem Biophys Res Commun 297:987-996

Minor LB, Schessel DA, Carey JP (2004) Meniere's disease. Curr Opin Neurol 17:9-16

Miyabe Y, Kikuchi T, Kobayashi T (2002) Comparative immunohistochemical localization of aquaporin-1 and aquaporin-4 in the cochlea of three different species of rodents. Tohoku J Exp Med 196:247-257

Neely JD, Amiry-Moghaddam M, Ottersen OP, Froehner SC, Agre P, Adams ME (2001) Syntrophin-dependent expression and localization of aquaporin-4 water channel protein. Proc Natl Acad Sci USA 98:14108-14113

Ohshiro K, Yaoita Y, Fujinaka H, Matsuki A, Kamiie J, Kovalenko P, Yamamoto $\mathrm{T}$ (2001) Expression and immunolocalization of AQP6 in intercalated cells of the rat kidney collecting duct. Arch Histol Cytol 64:329-338

Paparella MM (1984) Pathogenesis of Meniere's disease and Meniere's syndrome. Acta Otolaryngol Suppl 406:10-25

Perin P, Tritto S, Botta L, Fontana JM, Gastaldi G, Masetto S, Tosco M, Laforenza U (2010) Aquaporin-6 expression in the cochlear sensory epithelium is downregulated by salicylates. J Biomed Biotechnol (doi:10.1155/2010/264704)

Pitovski DZ, Kerr TP (2002) Sodium- and potassium-activated ATPase in the mammalian vestibular system. Hear Res 171: 51-65

Promeneur D, Kwon TH, Yasui M, Kim GH, Froklaer J, Knepper M, Agre P, Nielsen S (2000) Regulation of AQP6 mRNA protein expression in rats in response to altered acid-base or water balance. Am J Physiol Renal Physiol 279:1014-1026

Rangan GK, Tesch GH (2007) Quantification of renal pathology by image analysis. Nephrology 12:553-558

Rauch SD, Merchant SN, Thedinger BA (1989) Meniere's syndrome and endolymphatic hydrops. Double-blind temporal bone study. Ann Otol Rhinol Laryngol 98:873-883

Ross MD, Ernst SA, Kerr TP (1982) Possible functional roles of $\mathrm{Na}^{+}, \mathrm{K}^{+}-$ ATPase in the inner ear and their relevance to Meniere's disease. Am J Otolaryngol 3:353-360

Ruan RS (2002) Possible roles of nitric oxide in the physiology and pathophysiology of the mammalian cochlea. Ann N Y Acad Sci 962:260-274

Russell JM (2000) Sodium-potassium-chloride cotransport. Physiol Rev 80:211-276

Salt AM, Melichar I, Thalmann R (1987) Mechanisms of endocochlear potential generation by stria vascularis. Laryngoscope 97:984-991

Sawada S, Takeda T, Kitano H, Takeuchi S, Kakigi A, Azuma H (2002) Aquaporin-2 regulation by vasopressin in the rat inner ear. Neuroreport 13:1127-1129 
Semaan MT, Alagramam KN, Megerian CA (2005) The basic science of Meniere's disease and endolymphatic hydrops. Curr Opin Otolaryngol Head Neck Surg 13:301-307

Stankovic KM, Adams JC, Brown D (1995) Immunolocalization of aquaporin CHIP in the guinea pig. Am J Physiol 269: $1450-1456$

Stankovic KM, Brown D, Alper SL, Adams JC (1997) Localization of $\mathrm{pH}$ regulating proteins $\mathrm{H}^{+}$ATPase and $\mathrm{Cl}^{-} / \mathrm{HCO}_{3}{ }^{-}$exchanger in the guinea pig inner ear. Hear Res 114:21-34

Taguchi D, Takeda T, Kakigi A, Okada T, Nishioka R, Kitano H (2008) Expression and immunolocalization of aquaporin-6 (Aqp6) in the rat inner ear. Acta Otolaryngol 128: $832-840$

Takumi Y, Kagelhus EA, Eidet J, Matsubara A, Usami S, Shinkawa H, Nielsen S, Ottersen OP (1998) Select types of supporting cell in the inner ear express aquaporin-4 water channel protein. Eur J Neurosci 10:3584-3595

Tran ND, Kim S, Vincent HK, Rodriguez A, Hinton DR, Bullock MR, Young HF (2009) Aquaporin-1 mediated cerebral edema follow- ing traumatic brain injury: effects of acidosis and corticosteroid administration. J Neurosurg 112:1095-1104

Vatassery GT, Santa Cruz KS, deMaster EG, Quach HT, Smith WE (2004) Oxidative stress and inhibition of oxidative phosphorylation induced by peroxynitrite and nitrite in rat brain subcellular fractions. Neurochem Int 45:963-970

Verkman AS, Mitra AK (2002) Structure and function of aquaporin water channels. Am J Physiol 278:13-28

Vidarsson H, Westergren R, Heglind M, Blomqvist SR, Breton S, Enerbäck S (2009) The forkhead transcription factor Foxil is a master regulator of vacuolar H-ATPase proton pump subunits in the inner ear, kidney and epididymis. PLoS ONE 4:e4471

Yamakawa K (1938) Über die pathologische Veränderung bei einem Meniere-Kranken. Z Otol Rhinol Laryngol 34:181

Yasui M, Hazama A, Kwon TH, Nielsen S, Guggino WB, Agre P (1999) Rapid gating and anion permeability of an intracellular aquaporin. Nature 402:184-187

Zelenina M, Zelenin S, Aperia A (2005) Water channels (aquaporins) and their role for postnatal adaptation. Pediatr Res 57:47-53 